\title{
Leokadia Oręziak
}

\section{TTIP - Transatlantyckie Partnerstwo w sprawie Handlu i Inwestycji - źródłem zagrożeń dla gospodarki i społeczeństwa}

\begin{abstract}
Streszczenie
TTIP - Transatlantyckie Partnerstwo w sprawie Handlu i Inwestycji to umowa, która niesie wiele zagrożeń dla gospodarki, środowiska naturalnego, praw konsumenta, praw pracowniczych oraz dostępności do usług publicznych w państwach Unii Europejskiej. Zawarte w umowie mechanizmy, w tym dotyczące rozstrzygania sporów między państwami a inwestorami zagranicznymi, oznaczają także liczne zagrożenia dla demokracji. Korzyści, które mają wynikać z realizacji tej umowy, przypadną przede wszystkim wielkim korporacjom uczestniczącym w handlu transatlantyckim, zagrożenia będą dotyczyły przede wszystkim obywateli i społeczeństw państw unijnych. Przewidywane niemal powszechne stosowanie, w wyniku umowy, zasady wzajemnego uznawania przepisów, oznaczać będzie w praktyce obniżenie zabezpieczeń chroniących prawa obywateli, pracowników i konsumentów w Unii Europejskiej. Liberalizacja handlu w ramach TTIP będzie czynnikiem wymuszającym zwiększoną konkurencję również wobec małych i średnich firm polskich, a w rezultacie także presję na zmniejszenie płac i innych kosztów, w tym związanych z koniecznością przestrzegania norm czy standardów. Zagrożeń jest więc zdecydowanie więcej niż korzyści.
\end{abstract}

Słowa kluczowe: TTIP, liberalizacja handlu, zagrożenia demokracji, korzyści korporacji $\mathrm{z}$ handlu transatlantyckiego, sprzeciw obywatelski

\section{The Transatlantic Trade and Investment Partnership as a source of threat to the economy as well as society}

\begin{abstract}
TTIP - the Transatlantic Trade and Investment Partnership is an agreement that carries a number of risks for the economy, the natural environment, consumer rights, labour rights and access to public services in the European Union. The mechanisms included in the
\end{abstract}


agreement, concerning the settlement of disputes between states and foreign investors, pose a number of threats to democracy as well. The benefits that are supposed to result from the implementation of the agreement will primarily be reaped by large corporations involved in the transatlantic trade. Mostly the citizens and societies of the EU member states will be under threat from the agreement. The principle of mutual recognition of regulations, which is expected to be practically universally used in accordance with the agreement, will mean in practice lowering safeguards protecting the rights of citizens, workers and consumers in the European Union. The liberalization of trade within the TTIP will be a factor forcing increased competition also in relation to the Polish small and medium-sized enterprises, and as a result, putting also pressure to reduce wages and other costs, including those related to the need of complying with the norms or standards. Thus, there are far more threats than benefits of the agreement.

Keywords: TTIP, trade liberalization, threats to democracy, benefits from transatlantic trade for corporations, civil disobedience/opposition

Transatlantyckie Partnerstwo w sprawie Handlu i Inwestycji (Transatlantic Trade and Investment Partnership - TTIP) to umowa negocjowana od lipca $2013 \mathrm{r}$. między Stanami Zjednoczonymi Ameryki a Unią Europejską. Pod naciskiem opinii publicznej państw członkowskich Rada Unii Europejskiej w październiku 2014 r. podjęła decyzję o ujawnieniu mandatu negocjacyjnego, zaakceptowanego przez nią ponad rok wcześniej (17 czerwca 2013 r. $)^{1}$. Opublikowanie tego dokumentu nastąpiło zatem po upływie stosunkowo długiego okresu od rozpoczęcia negocjacji i było rezultatem silnej presji społecznej. Bardzo wiele organizacji z państw członkowskich domagało się ujawnienia zarówno założeń, jak i celów porozumienia negocjowanego ze Stanami Zjednoczonymi.

Powstały liczne inicjatywy społeczne przeciw umowie TTIP, w tym Europejska Inicjatywa Obywatelska „Stop TTIP”. Pod wystosowanym przez nią apelem o wstrzymanie negocjacji podpisało się ponad 3 mln osób z państw członkowskich Unii Europejskiej². Komisja Europejska, prowadząca w imieniu Unii negocjacje ze Stanami Zjednoczonymi, nie tylko nie zareagowała pozytywnie na ten apel, ale zapowiedziała zwiększenie wysiłku, by negocjacje przyspieszyć. Takie podejście Komisji jest m.in. rezultatem apeli kierowanych do niej przez przywódców niektórych państw Unii,

1 Declassification of document ST 11103/13 Restraint UE/EU Restricted dated 17 June 2013. New status: Public. Directives for the negotiation on the Transatlantic Trade and Investment Partnership between the European Union and the United States of America, Brussels, 9 October 2014, 11103/13, http://data.consilium.europa.eu/doc/document/ST-11103-2013-DCL-1/en/pdf

2 L. Raś, Cornelia Reetz o TTIP: Demokracja nie może być dostosowywana do wymogów rynku, http:// biznes.gazetaprawna.pl/artykuly/898762, cornelia-reetz-o-ttip-stop-ttip-isds-ics-wywiad.html, dostęp 9.10.2015. 
w tym premiera Wielkiej Brytanii D. Camerona oraz kanclerz Niemiec A. Merkel, opowiadających się za możliwie szybkim zawarciem umowy TTIP³.

Parlament Europejski w czerwcu 2015 r. podjął uchwałę w sprawie negocjacji dotyczących TTIP uznając, że powinny one być kontynuowane, wskazując jednocześnie, że poważnie powinien zostać zmieniony mechanizm rozstrzygania sporów między zagranicznymi inwestorami a państwami, na obszarze których ci inwestorzy działają, czyli mechanizm ISDS (Investor - State Dispute Settlement) ${ }^{4}$.

Podjęcie przez Stany Zjednoczone i Unię Europejską negocjacji w sprawie TTIP, a także innych układów o wolnym handlu i inwestycjach, stanowi odejście od zasad, które przez wiele dziesięcioleci obowiązywały w handlu międzynarodowym. Ukształtowany po drugiej wojnie światowej system wielostronnego handlu (multilateral trade system), choć daleki od doskonałości, oceniany jest jako system, który pozwolił istotnie ograniczyć ryzyko wojen handlowych między różnymi państwami i stał się istotnym czynnikiem rozwoju gospodarki światowej. Sprzyjał temu proces redukowania ceł oraz innych ograniczeń, realizowany dzięki kolejnym rundom negocjacji w ramach GATT (General Agreement on Tariffs and Trade), a od 1995 r. w ramach Światowej Organizacji Handlu (World Trade Organization - WTO).

W ostatnich kilkunastu latach, a zwłaszcza w ostatnim dziesięcioleciu, istotną przeszkodą w funkcjonowaniu tej organizacji stała się trudna do przezwyciężenia rozbieżność celów między głównymi grupami jej państw członkowskich, wyrażająca się przede wszystkim tym, że państwa rozwijające się są zasadniczo przeciw szerokiemu otwarciu swoich rynków na eksport z państw wysoko rozwiniętych, zarówno jeśli chodzi o towary przemysłowe, jak i produkty rolne. Tymczasem tym ostatnim państwom na takim właśnie otwarciu zależy od dawna, w tym na wyeliminowaniu bądź znacznym ograniczeniu także - wszelkich innych niż cła - barier w dostępie do rynków państw rozwijających się. Stąd wynikło niepowodzenie rundy wielostronnych negocjacji w ramach WTO, określanej jako runda Doha. W tej sytuacji państwa wysokorozwinięte, a przede wszystkim Stany Zjednoczone, skoncentrowały swoje wysiłki na działaniach poza WTO i wynegocjowaniu swoistych megaumów o wolnym handlu, mających charakter regionalny, a mianowicie TTIP i TPP (Trans-Pacific Partnership), a poza tym umów o mniejszym zasięgu jak CETA (Comprehensive Economic and Trade Agreement), będącą umową między Unią Europejską a Kanadą. Jak

3 Q. Aries, H. von der Burchard, TTIP negotiations not even half done, "Politico" 2015, October 1.

4 Resolution of 8 July 2015 containing the European Parliament's recommendations to the European Commission on the negotiations for the Transatlantic Trade and Investment Partnership, http://www.europarl.europa.eu/sides/getDoc.do?pubRef=-//EP//TEXT+TA+P8-TA-2015-0252+0+DOC+XML+V0//EN 
się ocenia, wejście w życie tych umów poważnie osłabi rolę WTO jako organizacji wspierającej handel międzynarodowy5.

TTIP i TPP powszechnie określane są jako dwie tzw. megaumowy, co wskazuje, że mogą one mieć kluczowy wpływ nie tylko na handel w obrębie państw uczestniczących w tych umowach, ale również na cały handel światowy.

Jak pisze A. Deaton, laureat nagrody Nobla z 2015 r., państwa rozwijające się potrzebują lepszych niż dotychczas możliwości handlu z państwami wysokorozwiniętymi. Jest to kluczowy, jego zdaniem, warunek skutecznej walki z ubóstwem, zwłaszcza w Afryce. Ubóstwa tego nie da się zmniejszyć poprzez przekazywaną przez bogate państwa pomoc finansową, gdyż słabe struktury państwowe w państwach, do których jest ona kierowana, uniemożliwiają jej właściwe wykorzystanie. Poza tym pomoc taka podważa w praktyce rozwój ich własnego potencjału gospodarczego ${ }^{6}$.

\section{Lekcja wynikająca z umowy NAFTA}

Funkcjonujący od 1994 r. układ o wolnym handlu - NAFTA (North American Free Trade Agreement), został zawarty między Stanami Zjednoczonymi, Kanadą i Meksykiem. Na jego mocy przeprowadzono bardzo szeroką liberalizację wzajemnych obrotów handlowych. Układ ten obowiązuje dalej państwa będące jego stronami, zaś wynikające z niego doświadczenia powinny stanowić poważne ostrzeżenie dla państw, które miałyby uczestniczyć w podobnych porozumieniach w przyszłości. Warto podkreślić, że w wypadku umowy TTIP zakres liberalizacji byłby znacznie szerszy i wprowadzonych zostałoby wiele nowych elementów. Doświadczenia wynikające z funkcjonowania NAFTA pokazują, jak negatywne mogą być konsekwencje tego rodzaju umów, zwłaszcza dla państw słabszych ekonomicznie.

Wśród wielu analiz pokazujących skutki ponad 20 lat istnienia NAFTA dla Meksyku, na uwagę zasługuje ta, którą przeprowadzili M. Weisbrot, S. Lefebvre i J. Sammut ${ }^{7}$. Porównali oni wskaźniki ekonomiczne i społeczne odnoszące się do tego państwa ze wskaźnikami reszty państw regionu Ameryki Łacińskiej (które nie przystąpiły do NAFTA), jak również tymi wskaźnikami, które charakteryzowały Meksyk w okresie przed wejściem w życie układu NAFTA. Z porównania tego

5 H.C. Hufbauer, C. Cimino-Isaacs, How will TPP and TTIP Change the WTO System, "Journal of International Economic Law" 2015, September.

6 A. Deaton, Weak States, Poor Countries, https://www.project-syndicate.org/commentary/economicdevelopment-requires-effective-governments-by-angus-deaton, dostęp 18.10.2015.

7 M. Weisbrot, S. Lefebvre, J. Sammut, Did NAFTA Help Mexico? An Assessment After 20 Years, Center for Economic and Policy Research, Washington 2014. 
wynika, że po 20 latach uczestnictwa w porozumieniu NAFTA, sytuacja ekonomiczna i społeczna Meksyku jest znacznie gorsza w porównaniu z państwami wskazanego regionu nieuczestniczącymi $\mathrm{w}$ tym porozumieniu, a także $\mathrm{w}$ porównaniu $\mathrm{z}$ okresem sprzed 1994 r. Autorzy analizy wskazali m.in., że w ciągu 20 lat udziału w NAFTA realny PKB na mieszkańca wzrósł w Meksyku łącznie o około 19\% (reszta państw regionu odnotowała wzrost dwukrotnie wyższy), natomiast w okresie 1960-1980 wzrost ten był wielokrotnie wyższy i wynosił aż 99\%. Kluczowe znaczenie ma też fakt, że w Meksyku w 2012 r. wskaźnik ubóstwa (poverty rate) kształtował się na poziomie ok. 52\%, czyli wynosił tyle co w 1994 r. Uwzględniając ogólny wzrost liczby ludności od tego czasu widzimy, że w 2012 r. sytuacja była znacznie gorsza niż wtedy, gdy rozpoczęła się realizacja układu NAFTA, gdyż mieszkańców Meksyku, żyjących w ubóstwie było o ponad $14 \mathrm{mln}$ więcej niż w roku 1994.

W analizie, którą przeprowadzili M. Weisbrot, S. Lefebvre i J. Sammut, wiele miejsca poświęcono negatywnym skutkom realizacji układu NAFTA dla meksykańskiego rolnictwa i bezpieczeństwa żywnościowego ludności Meksyku. Istotne znaczenie ma tu fakt, że w ramach tego układu Stany Zjednoczone zawarły dwa odrębne porozumienia dotyczące rolnictwa: jedno z Kanadą, przewidujące stosowanie znaczących ograniczeń w dostępie do kanadyjskiego rynku rolnego, a drugie z Meksykiem, zakładające zniesienie niemal wszystkich barier chroniących rynek tego państwa przed produktami rolnymi z USA. Swobodny napływ silnie subsydiowanych przez państwo produktów ze Stanów Zjednoczonych do Meksyku skutkował upadkiem wielkiej liczby meksykańskich gospodarstw rolnych, oznaczającym likwidację niemal 2 mln miejsc pracy w rolnictwie. Przyczyniło się to do poważnej degradacji wielu obszarów wiejskich, a znaczna część zamieszkałej tam ludności musiała je opuścić i wyemigrować, głównie do Stanów Zjednoczonych (często nielegalnie), zasilając najuboższe grupy społeczne. Poważną konsekwencją pełnej liberalizacji przez Meksyk dostępu do swojego rynku dla produktów rolnych ze Stanów Zjednoczonych stał się wyraźny spadek bezpieczeństwa żywnościowego meksykańskiego społeczeństwa. Z badań, które przeprowadził T. Wise (Tufts University, Global Development and Environment Institute) wynika, że dzięki NAFTA eksport tych produktów ze Stanów Zjednoczonych do Meksyku zwiększył się tak znacznie, iż przyczynił się do drastycznego spadku cen m.in. kukurydzy (o 66\%) w ostatnich latach, w porównaniu z okresem sprzed $1994 \mathrm{r}$. Wyrazem wzrostu uzależnienia Meksyku od importu produktów rolnych jest fakt, że w połowie lat 2000 sprowadzał on z zagranicy aż $42 \%$ żywności, w tym głównie ze Stanów Zjednoczonych. Zwraca uwagę to, że zależność od importu kukurydzy zwiększyła się z 8\% w okresie sprzed NAFTA do 32\% w 2005 r., natomiast np. w wypadku pszenicy z $20 \%$ aż do $60 \%$. Konsekwencje tych zmian stały się silnie odczuwalne przez społeczeństwo Meksyku po tym, jak nastąpił gwałtowny wzrost 
cen produktów rolnych na rynku światowym w 2007 r. Ceny wielu podstawowych produktów rolnych wzrosły dwukrotnie, a niektórych nawet trzykrotnie ${ }^{8}$. L. Carlsen wskazuje, że ponad $20 \mathrm{mln}$ osób, czyli prawie jedna czwarta mieszkańców Meksyku, nie ma wystarczającego dostępu do produktów żywnościowych, a jedna piąta dzieci cierpi na skutek niedożywienia. Autor podkreśla, że stan ten jest skutkiem zmian, jakie nastąpiły w rolnictwie Meksyku w okresie udziału tego państwa w NAFTA9.

Negatywne doświadczenia Meksyku, związane z uczestnictwem w porozumieniu NAFTA, nie dotyczą tylko rolnictwa i bezpieczeństwa żywnościowego. Wiążą się one także z destrukcyjnym wpływem tego porozumienia na sektor przemysłowy. Praktyka pokazała, że przemysł meksykański nie był w stanie na rynku krajowym skutecznie konkurować $\mathrm{z}$ towarami pochodzącymi ze Stanów Zjednoczonych, a na rynku amerykańskim z towarami pochodzącymi z Chin. Cytowane wyżej analizy zwracają uwagę na konsekwencje układu NAFTA dla Meksyku, oznaczające poza destrukcją rolnictwa także poważną destrukcję przemysłu.

Państwa zamierzające włączyć się do takiego rodzaju porozumienia jak TTIP, szeroko liberalizującego dostęp do rynku krajowego dla charakteryzujących się relatywnie wysokim poziomem technologicznym towarów ze Stanów Zjednoczonych, nie mogą pominąć tych doświadczeń. Można oczekiwać, że wynikające z TTIP potencjalne zagrożenia dla polskiego przemysłu i rolnictwa okażą się znacznie większe niż korzyści mogące wyniknąć dla przedsiębiorstw z tytułu wyeliminowania barier w dostępie do rynku Stanów Zjednoczonych. Wiąże się to z wyraźnie niższą konkurencyjnością wielu polskich towarów, jeżeli chodzi o ich poziom technologiczny. Ponadto, podobnie jak Meksyk, Polska ma dość ograniczone możliwości skutecznej konkurencji na rynku Stanów Zjednoczonych z tanimi towarami z Chin. Wprawdzie koszty robocizny w Polsce należą do najniższych w państwach OECD, są jednak znacznie wyższe niż w Chinach.

\section{TPP - Partnerstwo Transpacyficzne}

Trwające ponad pięć lat negocjacje w sprawie umowy TPP (Trans-Pacific Partnership), prowadzone w ścisłej tajemnicy przed opinią publiczną, zakończyły się w październiku 2015 r. Umowa ta obejmuje 12 państw (Stany Zjednoczone, Japonia,

8 T.A. Wise, How Beer Explains 20 Years of NAFTA 's Devastating Effects on Mexico, 2.01.2014, http:// www.globalpost.com/dispatches/globalpost-blogs/global-pulse/nafta-20-years-mexican-beer

9 L. Carlsen, Under Nafta, Mexico Suffered, and the United States Felt Its Pain, 24.11.2013, http://www. nytimes.com/roomfordebate/2013/11/24/what-weve-learned-from-nafta/under-nafta-mexico-sufferedand-the-united-states-felt-its-pain 
Australia, Kanada, Meksyk, Nowa Zelandia, Peru, Singapur, Wietnam, Malezja, Chile i Brunei). Państwa będące stronami umowy TPP tworzą niemal 40\% światowego PKB, przy czym połowa $z$ tego przypada na Stany Zjednoczone i Japonię. Prezydent Stanów Zjednoczonych, B. Obama, propaguje TPP jako rozwiązanie, które ma sprzyjać wzrostowi płac, utrzymaniu miejsc pracy, bardziej uczciwej konkurencji oraz ochronie środowiska naturalnego ${ }^{10}$.

Jak wskazuje J.-P. Lehmann (International Institute for Management Development w Lozannie), układ TPP należy widzieć jako geopolityczny sojusz między Stanami Zjednoczonymi a Japonią, wymierzony wyraźnie i otwarcie przeciw Chinom. Autor przytacza słowa prezydenta B. Obamy, z których wynika, że jeżeli Stany Zjednoczone nie określą reguł globalnego handlu w XXIw., służących amerykańskim firmom i pracownikom, to reguły te zostaną ustanowione przez Chiny na korzyść chińskich firm i pracowników. J.P. Lehmann zauważa, że państwo to zamiast być traktowane jak partner, jest atakowane jako rywal, co w opinii tego autora nie jest konieczne. Przeciwnie, by zapewnić trwały, dynamiczny i pokojowy rozwój gospodarki światowej, Chiny, Stany Zjednoczone oraz inne odpowiedzialne państwa powinny wspólnie wypracować reguły handlu międzynarodowego na XXI wiek ${ }^{11}$.

Zwolennicy umowy TPP, jak np. J. Frankel (Harvard University), propagując potencjalne korzyści mogące wyniknąć ze zniesienia ceł i barier pozacelnych w handlu między państwami będącymi stronami tej umowy, nie odnoszą się do fundamentalnych zagrożeń, jakie tego rodzaju porozumienia niosą w szczególności dla krajów słabszych ekonomicznie ${ }^{12}$.

Z kolei przeciwnicy umowy TPP, jak np. D. Baker (Center for Economic Policy Research, Waszyngton) wskazuje, że umowa ta służy realizacji tych celów, na których wielkim korporacjom zależy najbardziej. Chodzi tu w szczególności o ochronę patentową i prawa autorskie oraz zapewnienie stosowania mechanizmu ISDS, umożliwiającego tym inwestorom bezpośrednie pozywanie rządów państw członków porozumienia przed prywatne międzynarodowe trybunały arbitrażowe ${ }^{13}$.

A. Navarro, chilijski senator, stwierdził w październiku 2015 r., że TPP jest specyficznym, ukrytym sposobem na wprowadzenie wielu zmian, których międzynarodowe koncerny nie były w stanie przeprowadzić w parlamentach narodowych, jak

10 B. Obama, America's bold voice cannot be the only one, "Financial Times" 2015, November 12, http://www.ft.com/cms/s/0/2614c636-8930-11e5-90de-f44762bf9896.html\#axzz 33DKHrBd7

${ }^{11}$ J.P. Lehmann, TPP: The Path To Global Fragmentation, http://www.forbes.com/sites/jplehmann/ 2015/10/13/tpp-the-path-to-global-fragmentation/, dostęp 18.10.2015.

12 J. Frankel, Why Support the TPP? 8.10.2015, https://www.project-syndicate.org/commentary/why-support-tpp-by-jeffrey-frankel-2015-10

${ }_{13}$ D. Baker, The TPP's Children 's Table: Labor Rights and Currency, http://www.truth-out.org/opinion/ item/33572-the-tpp-s-children-s-table-labor-rights-and-currency 
np. ograniczenie ochrony prywatności w Internecie, zwiększenie ochrony patentowej oraz deregulacji finansowej. Dla Chile umowa TPP oznacza m.in. ograniczenie co najmniej na pięć lat możliwości obniżenia cen leków ze względu na ochronę patentową zagwarantowaną firmom farmaceutycznym. Senator Navarro podkreślił, że wejście w życie tej umowy będzie oznaczało skazanie $792 \mathrm{mln}$ osób (łączna liczba ludności 12 państw będących sygnatariuszami TPP) na zależność i podporządkowanie międzynarodowym koncernom farmaceutycznym, dążącym do zachowania swoich zysków. Będzie oznaczało ograniczenie dostępu do leków generycznych, które są zdecydowanie tańsze niż oryginalne. Dla państwa rozwijającego się, takiego jak Chile, oznacza to wyrok śmierci dla tysięcy obywateli, których nie stać na drogie leki, $\mathrm{w}$ tym przeciwnowotworowe. W rezultacie, w jego opinii, realizacja umowy TPP jest frontalnym atakiem na politykę publiczną, mającą na celu rozszerzenie dostępu do usług ochrony zdrowia. $\mathrm{Z}$ tego względu, a także wielu innych wynikających z zapisów zawartych w umowie TPP, jej odrzucenie jest więc niezbędne, by chronić prawa obywateli oraz społeczną, ekonomiczną i polityczną suwerenność Chile ${ }^{14}$.

Jak zauważa M. Weisbrot (Center for Economic and Policy Research, Waszyngton), łączne korzyści, jakie mogą osiągnąć Stany Zjednoczone z realizacji umowy TPP są bardzo niewielkie. $Z$ dostępnych szacunków wynika bowiem, że po pierwszych 10 latach funkcjonowania tej umowy w praktyce łączny wzrost amerykańskiego PKB może wynieść $0,4 \%$, przy czym podkreśla, że nie byłby to wzrost roczny, ale za cały okres. Oznacza to, że wzrost ten byłby w istocie niezauważalny, zaś mechanizmy zwiększonej konkurencji, które byłyby uruchomione w wyniku TPP, przyczyniłyby się do wzrostu nierówności dochodowych w Stanach Zjednoczonych, gdyż z powodu realizacji tej umowy większość pracowników znalazłaby się w gorszej sytuacji niż dotychczas. Ponadto, przewidziane tą umową zwiększenie i wydłużenie ochrony patentowej i praw autorskich byłoby dodatkowym czynnikiem dystrybucji dochodów na rzecz bogatszej części społeczeństwa. Weisbrot zauważa także, że przy ocenie TPP należy wziąć pod uwagę doświadczenia wynikające $\mathrm{z}$ funkcjonowania układu NAFTA. Podobnie jak TPP, układ ten, w jego opinii, miał przede wszystkim na celu rozszerzenie praw i przywilejów dla inwestorów, będących głównie wielonarodowymi korporacjami, w tym dzięki zastosowaniu mechanizmu ISDS ${ }^{15}$.

Największe korzyści, jakie mogą wyniknąć dla USA z umowy TPP, dotyczą produktów rolnych. Wskazuje na to K. Hamada (University of Tokyo) podkreślając, że korzyści te pociągną za sobą znaczne poświęcenia ze strony innych państw

14 TPP es un tratado que nos somete a las farmacéuticas y al poder corporativo, http://www.navarro. cl/tpp-es-un-tratado-que-nos-somete-a-las-farmaceuticas-y-al-poder-corporativo/, dostęp 5.10.2015.

${ }^{15} \mathrm{M}$. Weisbrot, Lessons from NAFTA for the TPP, http://www.cepr.net/publications/op-eds-columns/lessons-from-nafta-for-the-tpp, dostęp 18.10.2015. 
uczestniczących w tym porozumieniu, w tym Japonii. Jednocześnie dodaje, że akurat jego państwo zdołało w ramach tej umowy wywalczyć znaczącą liberalizację dostępu dla swoich samochodów osobowych i ciężarowych do rynku Stanów Zjednoczonych. To z kolei jednak wywołuje silny protest amerykańskich związków zawodowych (m.in. United Automobile Workers), obawiających się negatywnych skutków dla krajowego przemysłu samochodowego ${ }^{16}$.

Dokonując charakterystyki TPP, J.E. Stiglitz (Columbia University, laureat Nagrody Nobla) i A.S. Hersh (Roosevelt Institute) zwrócili uwagę, że to największe w historii regionalne porozumienie handlowe i inwestycyjne realizuje interesy najbardziej wpływowych grup biznesowych z państw będących jego sygnatariuszami. TPP nie jest $\mathrm{w}$ istocie o „wolnym” handlu pomiędzy tymi państwami, a wręcz przeciwnie. Najbardziej wpływowe grupy wielkiego kapitału z tych państw wywalczyły dla siebie uprzywilejowaną pozycję w handlu kosztem innych producentów, także z tych samych państw. Postanowienia TPP dotyczące m.in. ochrony patentowej farmaceutyków ograniczą otwartą konkurencję i przyczynią się do wzrostu cen, zarówno w Stanach Zjednoczonych, jak i w całym świecie, co jest faktycznie zaprzeczeniem idei wolnego handlu. Autorzy podkreślają, że TPP reguluje handel farmaceutykami poprzez różne specyficzne rozwiązania dotyczące patentów (patent linkage), wyłączności na korzystanie z danych (data exlusivity) oraz kwestii biologicznych (biologics). Stosowanie tych rozwiązań oznacza, że firmy farmaceutyczne będą mogły efektywnie wydłużyć ustalony 5-letni okres ochrony, czasami praktycznie w nieskończoność. Pozwoli im to na zachowanie monopolu w dziedzinie leków opatentowanych, blokując wejście na rynek leków generycznych, a także konkurencyjnych leków, zbliżonych do produktów biologicznych (biosimilar) ${ }^{17}$.

K. Hamada (University of Tokyo) przewiduje, że jeżeli umowa TPP zostanie ratyfikowana i wejdzie w życie, to będzie miała zarówno ogromny wpływ na handel i przepływ kapitału w regionie Pacyfiku, jak i przyczyni się do transformacji międzynarodowego ładu ${ }^{18}$.

TPP stanowić może istotny krok w kierunku destrukcji istniejącego dotychczas systemu handlu międzynarodowego. Zwraca na to uwagę J.-P. Lehmann wskazując, że ten system wielostronnych obrotów handlowych spajał świat od ponad sześciu dziesięcioleci, a umowa TPP stanowi kolejny „gwóźdź do trumny” tego systemu ${ }^{19}$.

${ }^{16}$ K. Hamada, The Fraught Politics of the TPP, https://www.project-syndicate.org/commentary/tppeconomic-gains-political-obstacles-by-koichi-hamada-2015-10, dostęp 31.10.2015.

17 J.E. Stiglitz, A.S. Hersh, The Trans-Pacific Free-Trade Charade, 2.10.2015, https://www.project-syndicate.org/commentary/trans-pacific-partnership-charade-by-joseph-e--stiglitz-and-adam-s--hersh-2015-10

18 K. Hamada, op.cit.

19 J.P. Lehmann, TPP: The Path To Global Fragmentation, op.cit. 
Już teraz układ TPP postrzegany jest jako swoisty „złoty standard” dla globalnego handlu. Układ ten obejmuje nie tylko handel, ale wiele innych obszarów jak inwestycje, usługi, przepływ danych, ochronę własności intelektualnej, handel elektroniczny, a także przepływ pracowników ${ }^{20}$.

\section{Potencjalne korzyści i zagrożenia związane z TTIP}

Wśród argumentów mających, według zwolenników TTIP, przemawiać za tą umową wskazuje się przede wszystkim oczekiwane, dzięki mechanizmowi wolnego handlu, przyspieszenie wzrostu gospodarczego w państwach Unii Europejskiej i Stanach Zjednoczonych. Argumenty te zostały zaprezentowane m.in. przez Centre for Economic Policy Research (CEPR) w opracowaniu opublikowanym w marcu 2013 r., a przygotowanym na zamówienie Komisji Europejskiej ${ }^{21}$. Wskazano w nim, że szacowane korzyści z realizacji umowy w okresie do 2027 r. w kształcie uznanym przez autorów za najbardziej prawdopodobny, to dodatkowy wzrost gospodarczy w wysokości 0,4\% PKB Stanów Zjednoczonych oraz 0,5\% Unii Europejskiej. Oznaczałoby to dodatkowy wzrost PKB o 0,04 p.p. i 0,05 p.p. rocznie w okresie 10 lat, czyli w praktyce bardzo nieznaczny. Ten bardzo niski w istocie dodatkowy wzrost gospodarczy silnie kontrastuje z relatywnie dużym wzrostem eksportu Unii Europejskiej do Stanów Zjednoczonych w tym okresie, szacowanym przez CEPR na 28\%. Można postawić wniosek, że wzrost eksportu, oczekiwany w wyniku realizacji TTIP, praktycznie nie przełoży się na jakiś zauważalny dodatkowy wzrost gospodarczy w badanym okresie. Trzeba też dodać, że Komisja Europejska, charakteryzując we wrześniu 2013 r. główne elementy opracowania CEPR ${ }^{22}$, wskazała na to, iż jego autorzy nie badali wpływu TTIP na tworzenie nowych miejsc pracy.

Obszerną analizę wyników badań przedstawionych we wskazanym opracowaniu CEPR, a także rezultatów prac badawczych zawartych w innych opracowaniach prezentujących korzyści z funkcjonowania TTIP, przedstawili W. Raza i B. Tröster (Austrian Foundation for Development Research - ÖFSE). Autorzy ci podkreślają, że w opracowaniach pokazujących TTIP jako rozwiązanie korzystne tak dla gospodarki

${ }^{20}$ G. Isfeld, Forget NAFTA, the TPP is the new 'gold standard' of global trade,_http://business.financialpost.com/news/economy/forget-nafta-the-tpp-is-the-new-gold-standard-of-global-trade

${ }^{21} \mathrm{~J}$. Francois et al., Reducing Transatlantic Barriers to Trade and Investment An Economic Assessment Final Project Report, March 2013 Prepared under implementing Framework Contract TRADE10/A2/A16, Centre for Economic Policy Research, London, http://trade.ec.europa.eu/doclib/docs/2013/march/tradoc_150737.pdf

${ }^{22}$ European Commission, Transatlantic Trade and Investment Partnership. The Economic Analysis Explained, September 2013, http://trade.ec.europa.eu/doclib/docs/2013/september/tradoc_151787.pdf 
Stanów Zjednoczonych, jak i państw Unii Europejskiej, w ogóle nie wzięto pod uwagę kosztów dostosowania się tych państw do rozwiązań, które miałyby być zawarte w umowie. Najwięcej zastrzeżeń wzbudził fakt nieuwzględnienia kosztów społecznych, a także kosztów dla finansów publicznych. Opracowania propagujące TTIP całkowicie pomijają także zagrożenia dla demokracji mogące wynikać ze stosowania mechanizmu ISDS ${ }^{23}$.

Korzyści z umowy TTIP, propagowane przez jej zwolenników, w wątpliwość podaje także D. Baker, wskazując, że dodatkowy wzrost gospodarczy, oczekiwany w efekcie stosowania umowy, nie tylko nie oznacza dodatkowego wzrostu zatrudnienia, ale prowadzić będzie do utraty miejsc pracy, szczególnie w krótkim okresie. Ponadto, jak zauważa Baker, szacunki dokonane przez CEPR nie uwzględniają możliwości powstania nowych barier dla wzrostu gospodarczego. Jedną z nich może być zwiększenie ochrony patentowej, w tym dotyczącej farmaceutyków, prowadzącej w rezultacie do wzrostu ich cen. Ten wzrost może prowadzić do zjawiska zbliżonego do tego, jakie występuje, gdy rosną cła na import, jednak jest tu istotna różnica. Polega ona na tym, że państwa wysoko rozwinięte rzadko obecnie stosują cła wyższe niż 20-30\%, natomiast to ochrona patentowa może przyczynić się do wzrostu cen farmaceutyków nawet o kilka tysięcy procent powyżej ich cen rynkowych ${ }^{24}$.

Wśród badań, które uwzględniają nie tylko potencjalne konsekwencje ekonomiczne umowy TTIP, ale przede wszystkim jej skutki społeczne, do najbardziej znaczących należą te, które przeprowadził J. Capaldo (Tufts University). Ich wyniki, opublikowane w październiku 2014 r., pokazują, że negatywne konsekwencje umowy mogą być bardzo poważne, zwłaszcza dla rynku pracy ${ }^{25}$. Z szacunków dokonanych przez Capaldo wynika, że w państwach Unii Europejskiej może dojść do utraty co najmniej 600 tys. miejsc pracy.

Jeśli chodzi o potencjalne skutki umowy TTIP dla rolnictwa, to w raporcie opublikowanym we wrześniu 2014 r. przez Parlament Europejski, wskazuje się, że do 2025 r. wartość dodana wytwarzana w rolnictwie Unii Europejskiej może ulec zmniejszeniu o 0,5\%, przy czym największy spadek możliwy jest w państwach bałtyckich, bo aż o 1,3\% (w wypadku Polski spadek ten może wynieść 0,1\%), natomiast w rolnictwie Stanów Zjednoczonych wartość ta może zwiększyć się o 0,4\%. Państwo to bowiem

${ }^{23}$ W. Raza, B. Tröster, Assessing the Claimed Benefits of the Transatlantic Trade and Investment Partnership, http://www2.euromemorandum.eu/uploads/raza_assessing_the_claimed_benefits_of_the_transatlantic_ttip.pdf

${ }^{24}$ D. Baker, The Risks of the Transatlantic Trade and Investment Partnership, "Intereconomics" 2014, No. 3, s. 179-180.

${ }^{25}$ J. Capaldo, The Trans-Atlantic Trade and Investment Partnership: European Desintegration, Unemployment and Instability, Global Development And Environment Institute at Tufts University, GDAE Working Paper 2014, No. 3, http://ase.tufts.edu/gdae/policy_research/TTIP_simulations.html 
istotnie skorzysta z planowanego w ramach TTIP zniesienia przez UE ceł na produkty rolne. Poza cłami Unia stosuje różne regulacje odnoszące się do produktów rolnych, a stanowiące faktycznie bariery pozataryfowe w handlu ze Stanami Zjednoczonymi (a także z innymi państwami). Z raportu Parlamentu Europejskiego wynika, że jeżeli stosowana dotychczas ochrona unijnego rolnictwa zostanie zmniejszona w efekcie umowy TTIP, to nawet w wypadku umiarkowanego wariantu liberalizacji (przewidującego 3-5 letnie okresy przejściowe wobec najbardziej wrażliwych produktów) w okresie do 2025 r. nastąpi bardzo duży, bo wynoszący aż o 116\%, wzrost wolumenu eksportu produktów rolnych ze Stanów Zjednoczonych na rynek Unii Europejskiej. Tymczasem wolumen eksportu tych produktów z Unii na rynek Stanów Zjednoczonych wzrósłby tylko o $56 \%{ }^{26}$. Trzeba podkreślić, że między Stanami Zjednoczonymi a Unią Europejską istnieją znaczące różnice w takich kluczowych kwestiach jak ochrona konsumenta, w tym w odniesieniu do wymagań, jakie powinny spełniać produkty żywnościowe. Z punktu widzenia konsumentów z Unii Europejskiej fundamentalne znaczenie ma to, że w wielu dziedzinach producenci rolni z państw członkowskich oraz przemysł przetwórczy podlegają znacznie bardziej restrykcyjnym wymaganiom (w tym dotyczącym ochrony środowiska, stosowania środków chemicznych, dobrostanu roślin i zwierząt) niż te, które obowiązują w Stanach Zjednoczonych. W cytowanym raporcie Parlamentu Europejskiego wskazuje się, że jeżeli zostałyby zniesione cła, a te istniejące normy i standardy nie uległyby odpowiedniej harmonizacji (zbliżeniu), to powstałoby poważne ryzyko zakłócenia konkurencji na rynku Unii. Byłoby ono efektem tego, że na jednolitym unijnym rynku konkurowaliby między sobą producenci podlegający zupełnie odmiennym wymaganiom. Producenci rolni z państw członkowskich Unii mieliby więc z tego powodu gorszą pozycję konkurencyjną, na którą ponadto negatywny wpływ miałyby występujące w tych państwach wyższe koszty energii i pracy niż w Stanach Zjednoczonych. Można zatem założyć, że bez harmonizacji stosowanych przez obie strony regulacji, czyli uzgodnienia pewnego minimum wymagań, bardziej konkurencyjny cenowo import rolny ze Stanów Zjednoczonych stałby się istotnym zagrożeniem dla rolnictwa w Unii Europejskiej. Trzeba jednak podkreślić, że taka harmonizacja mogłaby oznaczać obniżenie unijnych standardów, gdyż trudno oczekiwać, że amerykańscy producenci rolni zgodzą się na podwyższenie istniejących wymagań. Uzasadnione są więc obawy, że w wyniku umowy TTIP uruchomiony zostanie swoisty „wyścig do dna” w sektorze produktów

${ }^{26}$ J.Ch. Bureau et al., Risks and Opportunities for the EU Agri-Food Sector in a Possible EU-US Trade Agreement, European Parliament, Directorate-General for Internal Policies, http://www.europarl.europa. eu/RegData/etudes/STUD/2014/514007/AGRI_IPOL_STU\%282014\%29514007_EN.pdf, s. 34-47. 
rolnych, ze wszystkimi związanymi z tym zagrożeniami dla zdrowia i bezpieczeństwa konsumentów, a także ochrony środowiska.

Ocena potencjalnych korzyści ekonomicznych mogących wynikać w praktyce z umowy TTIP wymaga uwzględnienia nie tylko tego, komu te korzyści przypadną i jak będą rozłożone w czasie. Konieczne jest uwzględnienie także tego, jakie koszty społeczne i ekonomiczne będą musiały ponieść państwa mające uczestniczyć w realizacji tej umowy. S. Dullien, A. Garcia i J. Janning oszacowali ekonomiczne skutki TTIP dla poszczególnych państw Unii Europejskiej, biorąc pod uwagę m.in. takie czynniki jak udział eksportu danego państwa na rynek Stanów Zjednoczonych w jego łącznym eksporcie oraz w PKB, a także istniejący dotychczas poziom ochrony celnej rynku amerykańskiego w odniesieniu do towarów eksportowanych przez państwa UE. Na bazie tych szacunków autorzy sporządzili listę „zwycięzców” i „przegranych” (TTIP Winners and Loosers). W pierwszej grupie znalazły się m.in. Niemcy, Dania, Włochy, Holandia, Wielka Brytania i Hiszpania, zaś w drugiej Słowenia, Łotwa, Rumunia, jak również Polska, Czechy i Bułgaria ${ }^{27}$. Badania te wskazują, że umowa TTIP niesie bardzo zróżnicowane skutki dla poszczególnych państw Unii. Warto jednak podkreślić, że w społeczeństwach tych państw, które ewentualnie miałyby być największymi beneficjentami liberalizacji transatlantyckiego handlu, sprzeciw wobec umowy TTIP jest najsilniejszy spośród wszystkich państw Unii. Dotyczy to zwłaszcza Niemiec, gdzie inicjatywa „Stop TTIP” zyskała największe poparcie. W społeczeństwach tych państw wyższa niż gdzie indziej jest świadomość, że korzyści z tej liberalizacji przypadną przede wszystkim wielkim korporacjom, zaś zwykli obywatele będą musieli ponieść koszty społeczne tej umowy.

\section{ISDS - mechanizm rozstrzygania sporów między inwestorami zagranicznymi a państwami}

Do elementów planowanej umowy TTIP wzbudzających szczególny sprzeciw społeczny należy wskazany wyżej mechanizm ISDS dotyczący rozstrzygania sporów między inwestorami zagranicznymi a goszczącymi ich państwami. Stosowanie tego mechanizmu postrzegane jest jako jedno z kluczowych zagrożeń dla demokracji, związanych z umową TTIP, gdyż w praktyce oznaczałoby, że niepochodzące z demokratycznych wyborów korporacje międzynarodowe dyktowałyby to, jaką politykę powinny prowadzić demokratycznie wybrane parlamenty i rządy.

27 S. Dullien, A. Garcia, J. Janning, A Fresh Start for TTIP, “ECFR Policy Brief “ 2015, No. 124, European Council on Foreign Relations, www.ecfr.eu 
Społeczny sprzeciw wobec planów włączenia ISDS do umowy TTIP stał się do tego stopnia znaczący, że nawet sama komisarz UE ds. handlu, C. Malmström, działająca bardzo intensywnie na rzecz sfinalizowania negocjacji w sprawie umowy TTIP, stwierdziła we wrześniu 2015 r., że „ISDS jest obecnie najbardziej toksycznym skrótem w Europie", co w jej opinii stało się jednym z kluczowych zagrożeń dla powodzenia tych negocjacji ${ }^{28}$. W praktyce okazało się bowiem, że gdyby mechanizm ISDS został umieszczony w umowie TTIP, to stałaby się ona trudna do zaakceptowania dla wielu państw członkowskich Unii, w szczególności państw tzw. starej Unii, które dotychczas takiego mechanizmu nie stosowały w relacjach wzajemnych oraz z innymi państwami wysoko rozwiniętymi.

Warto podkreślić, że mechanizm ISDS już od lat 50. ubiegłego wieku występuje w zawieranych między różnymi państwami, głównie wysoko rozwiniętymi a rozwijającymi się, dwustronnych umowach o ochronie inwestycji. W początkowym okresie miał on służyć ochronie zagranicznych inwestorów w państwach rozwijających się przed wywłaszczeniem. Jak jednak pokazuje praktyka, wraz z upływem czasu mechanizm ten przekształcił się w sposób osiągania przez międzynarodowe korporacje ogromnych odszkodowań od rządów z tytułu utraty nie faktycznych, a potencjalnych (jeszcze nie zrealizowanych, a jedynie oczekiwanych) zysków na skutek wprowadzania przez państwo regulacji dotyczących różnych obszarów życia gospodarczego i społecznego. Regulacje te mogą odnosić się m.in. do ochrony praw konsumenta, środowiska naturalnego, bezpieczeństwa produktów czy praw pracowników. W ostatnich latach coraz częściej zaczęły być upubliczniane informacje o tym, jak w rzeczywistości wygląda stosowanie mechanizmu ISDS zawartego w dwustronnych umowach inwestycyjnych. Coraz powszechniejsza staje się też świadomość społeczna tego, jak wielkie mogą być obciążenia wynikające dla finansów publicznych tych państw, na które prywatne trybunały arbitrażowe nałożyły obowiązek wypłaty odszkodowań na rzecz inwestorów. Wśród wielu przykładów pokazujących patologię dotychczas funkcjonującego mechanizmu ISDS można wskazać na fakt wystąpienia przez szwedzką firmę Vattenfall do mającego w Waszyngtonie siedzibę sądu arbitrażowego (International Centre for Settlement of Investment Disputes) z roszczeniem wobec rządu Niemiec o odszkodowanie na kwotę 4,7 mld EUR za szkody związane z zamknięciem elektrowni atomowych w Brunsbüttel i Krümmel. Elektrownie te zostały zamknięte w ramach polityki odchodzenia od energii atomowej, podjętej w Niemczech w następstwie awarii w japońskiej elektrowni atomowej Fukushima (w marcu 2011 r.). Realizując tę politykę, niemiecki rząd cofnął zezwolenie na działalność ośmiu elektrowniom

${ }_{28}$ P. Ames, ISDS: The most toxic acronym in Europe, http://www.politico.eu/article/isds-the-most-toxic-acronym-in-europe/, dostęp 17.09.2015. 
atomowym, w tym dwu zarządzanym przez firmę Vattenfall ${ }^{29}$. Przykład ten pokazuje, że polityka ochrony środowiska naturalnego oraz zdrowia społeczeństwa, kształtowana przez demokratycznie wybrane władze państwa, może zostać zagrożona z powodu utraty potencjalnych zysków przez zagraniczną korporację.

Charakteryzując dotychczasowe stosowanie mechanizmu ISDS, określonego w licznych dwustronnych umowach o ochronie inwestycji (umów takich jest ponad 3 tys.), należy zwrócić uwagę przede wszystkim na wysoki stopień tajności i uznaniowości przy wydawaniu orzeczeń przez prywatne sądy arbitrażowe, tworzone odrębnie do rozstrzygania poszczególnych spraw. Charakterystyczną cechą funkcjonującego dotąd mechanizmu ISDS jest także brak trybu odwoławczego od tych orzeczeń. Ponadto okazało się, że zasądzane przez te sądy wysokie odszkodowania, które państwa powinny płacić korporacjom zagranicznym, niosą na ogół znaczące skutki dla finansów publicznych. Na ukształtowanie się wysoce negatywnego obrazu mechanizmu ISDS wpływ miał także występujący często konflikt interesów, bowiem sędziowie (arbitrzy) rozstrzygający spory rekrutowali się dotychczas z niewielkiej grupy prawników specjalizujących się w prawie międzynarodowym. Jak pokazuje praktyka, mogą oni reprezentować stronę pozywającą, a jednocześnie być arbitrem rozstrzygającym $\mathrm{w}$ innym powiązanym $\mathrm{z}$ daną sprawą sporze między korporacją a państwem, co wielokrotnie powoduje silny konflikt interesów.

Przeciwnicy włączenia mechanizmu ISDS do umowy TTIP podkreślają dotychczasowe negatywne doświadczenia wynikające ze stosowania go w ramach dwustronnych umów inwestycyjnych, a w szczególności skłonność prywatnych sądów arbitrażowych do orzekania na korzyść wielonarodowych korporacji. W ten sposób sądy te uzyskały pozycję podmiotów stojących faktycznie ponad prawem narodowym, a nawet nad postanowieniami konstytucji pozywanych przed te sądy państw. Praktycznym efektem zasądzania przez prywatne sądy wysokich odszkodowań na rzecz korporacji stało się powstrzymywanie się przez rządy wielu państw od wydawania takich przepisów, które wprawdzie mogłyby być korzystne dla społeczeństwa (np. w dziedzinie ochrony środowiska czy ochrony zdrowia), ale mogłyby wpłynąć negatywnie na zyski oczekiwane przez inwestorów zagranicznych. W ten sposób, dzięki mechanizmowi ISDS, możliwe stało się oddziaływanie przez międzynarodowe korporacje na kształt stanowionego prawa w poszczególnych państwach, skutkujące faktycznym powstrzymywaniem się rządów od wprowadzania różnych potrzebnych społecznie regulacji, w obawie przed koniecznością płacenia gigantycznych odszkodowań korporacjom międzynarodowym.

${ }^{29}$ Vattenfall sues Germany over phase-out policy, http://www.world-nuclear-news.org/C-Vattenfall-sues-Germany-over-phase-out-policy-16101401.html 
Charakteryzując zagrożenia związane ze stosowaniem mechanizmu ISDS, J.E. Stiglitz i A.S. Hersh stwierdzają, że trudno sobie nawet wyobrazić, co by się zdarzyło, gdyby mechanizm ten można było zastosować wtedy, gdy odkryto śmiertelne właściwości azbestu. Zamiast zamykać fabryki i zmusić producentów do wypłaty odszkodowań dla osób, które ucierpiały z powodu tego materiału, w razie obowiązywania ISDS rządy musiałyby zapłacić tym producentom, by zaprzestali wytwarzania produktu zabijającego obywateli. Podatnicy w tym wypadku byliby uderzeni podwójnie - pierwszy raz, ponosząc koszty leczenia chorób spowodowanych azbestem, a drugi raz, finansując koszty odszkodowań, które państwo musiałoby wypłacić producentom za utracone $\mathrm{w}$ wyniku wprowadzenia regulacji zabraniających używania tego niebezpiecznego produktu zyski ${ }^{30}$.

Dotychczasowa praktyka stosowania ISDS w ramach bilateralnych umów inwestycyjnych wskazuje, że kwestie związane z ochroną środowiska należały do najczęściej występujących spraw przed prywatnymi sądami arbitrażowymi. I tak, warto zwrócić uwagę na to, że spośród 127 spraw skierowanych w ostatnich 20 latach w ramach mechanizmu ISDS przeciw państwom Unii Europejskiej, aż 60\% dotyczyło właśnie tych kwestii. Podatnicy z tych państw musieli pokryć koszty odszkodowań na kwotę ponad 3,5 mld USD wypłaconych inwestorom ${ }^{31}$.

Silna krytyka, z jaką spotkał się ten mechanizm, skłoniła Komisję Europejską do przedstawienia jego zmodyfikowanej wersji. Pierwsze zmiany zostały zaprezentowane w maju $2015 \mathrm{r}^{32}$. Propozycje te spotkały się także z poważną krytyką ze strony przeciwników TTIP. Następnie, 16 września 2015 r., Komisja Europejska zaproponowała kolejną wersję mechanizmu ISDS, a faktycznie zastąpienie go przez specjalny system sądów dla inwestorów zagranicznych (Investment Court System - ICS) ${ }^{33}$. Miałby on mieć charakter publiczny i składałby się z sądu pierwszej instancji oraz sądu apelacyjnego (w obecnym systemie prywatnych sądów arbitrażowych nie ma możliwości wniesienia odwołania od wydanego wyroku). Orzeczenia byłyby wydawane przez publicznie mianowanych sędziów o wysokich kwalifikacjach, porównywalnych do tych, jakimi muszą legitymować się sędziowie Międzynarodowego Trybunału

30 J.E. Stiglitz, A.S. Hersh, op.cit.

${ }^{31}$ A. Neslen, TTIP: EU negotiators appear to break environmental pledge in leaked draft, http://www. theguardian.com/business/2015/oct/23/ttip-eu-negotiators-appear-to-break-environmental-pledge-inleaked-draft, dostęp 23.10.2015.

32 CONCEPT PAPER Investment in TTIP and beyond - the path for reform. Enhancing the right to regulate and moving from current ad hoc arbitration towards an Investment Court, European Commission, http://trade.ec.europa.eu/doclib/docs/2015/may/tradoc_153408. PDF, dostęp 5.05.2015.

${ }_{33}$ Commission proposes new Investment Court System for TTIP and other EU trade and investment negotiations Brussels, 16 September 2015, http://europa.eu/rapid/press-release_IP-15-5651_en.htm oraz Commission draft text Transatlantic Trade and Investment Partnership TRADE IN SERVICES, INVESTMENT AND E-COMMERCE, http://trade.ec.europa.eu/doclib/docs/2015/september/tradoc_153807.pdf 
Sprawiedliwości (International Court of Justice). Postępowanie w ramach proponowanego przez Komisję sądowego systemu rozstrzygania sporów wnoszonych przez inwestorów przeciw państwom miałoby być transparentne i dostępne dla opinii publicznej.

Oceniając te propozycje Komisji dotyczące ICS, C. Reetz (koordynatorka Europejskiej Inicjatywy Obywatelskiej „Stop TTIP”) $)^{34}$ wskazuje, że zawierają one jedynie zmiany kosmetyczne w stosunku do tego, co Komisja Europejska proponowała wcześniej. Ponadto, wszystkie one odnoszą się tylko do kwestii proceduralnych, nie podważają natomiast całego systemu prywatnych sądów arbitrażowych. W jej opinii, nawet jeżeli sędziowie byliby powoływani w jawny sposób i byłaby możliwość odwołania się od orzeczenia, to nie zmieniłoby to faktu, że inwestorzy zagraniczni w dalszym ciągu mieliby możliwość omijania sądów krajowych. Zaś przed prywatnymi sądami arbitrażowymi mogliby powoływać się na tak zwane „pośrednie wywłaszczenie” - procedurę, która nie jest dopuszczalna przed sądami krajowymi i tym samym niedostępna dla krajowych firm. W rezultacie inwestorzy zagraniczni mogliby więc domagać się odszkodowań od poszczególnych państw za przyszłe, nie osiągnięte jeszcze, oczekiwane zyski. Z tego powodu, w jej opinii, zarówno ISDS, jak i ICS stanowią zagrożenie dla suwerenności państw i ich zdolności do działania $\mathrm{w}$ interesie publicznym, w tym w celu ochrony środowiska, zdrowia publicznego czy praw konsumenta.

Podobne zastrzeżenia wobec propozycji Komisji dotyczącej zastąpienia mechanizmu ISDS przez ICS zgłosili przedstawiciele wielu innych organizacji występujących przeciw TTIP ${ }^{35}$. Zwraca się w nich przede wszystkim uwagę na to, że proponowana reforma zakłada istnienie dyskryminacji między inwestorami, gdyż zapewnia tylko inwestorom zagranicznym prawo obchodzenia krajowych systemów prawnych oraz używania ponadnarodowych sądów do podważania decyzji rządów państw. To ponadnarodowe orzecznictwo stawia proces tworzenia prawa poza demokratyczną kontrolą. Sędziowie orzekający w procesach arbitrażowych ocenialiby, czy demokratycznie podjęte przez państwa decyzje są szkodliwe z punktu widzenia zagranicznych inwestorów. Wskazuje się, że ICS to kontynuacja mechanizmu ISDS oznaczającego, że utrzymuje się uprzywilejowany system wymiaru sprawiedliwości dla międzynarodowych korporacji, by chronić ich prywatne interesy.

${ }^{34}$ L. Raś, Cornelia Reetz o TTIP: Demokracja nie może być dostosowywana do wymogów rynku, http:// biznes.gazetaprawna.pl/galerie/898762, duze-zdjecie,1, cornelia-reetz-o-ttip-stop-ttip-isds-ics-wywiad. html, dostęp 9.10.2015.

${ }_{35}$ Zob. np. ISDS reform plan retains privileged corporate justice system, dostęp 16.09.2015. http://www. $\mathrm{s}^{2}$ bnetwork.org/isds-reform/; A. Wessels, EU Commission ISDS proposal - threat to democracy, https:// edri.org/enditorial-eu-commission-isds-proposal-threat-to-democracy/, dostęp 23.09.2015. 
Krytycy propozycji Komisji wskazują też, że „stary” mechanizm ISDS został zawarty w już wynegocjowanych (choć jeszcze nie ratyfikowanych) umowach o wolnym handlu z Kanadą i Singapurem, a także w ramach umowy TPP. Oznacza to, że jeśli te umowy weszłyby w życie, to zagraniczni inwestorzy będą mogli zaskarżać decyzje rządów państw Unii Europejskiej poprzez swoje filie znajdujące się w tych państwach. Warto zauważyć, że propozycja Komisji dotycząca ICS, stanowiąca próbę złagodzenia przynajmniej niektórych zagrożeń związanych z ISDS, niejako pośrednio potwierdza te zagrożenia. Powstaje zatem pytanie, dlaczego umowa CETA nie została dotychczas wycofana z procesu ratyfikacyjnego, skoro zawiera ona ten nieakceptowalny z punktu widzenia demokratycznych zasad mechanizm ISDS.

Trzeba zauważyć, że Stany Zjednoczone dalekie są od zaakceptowania proponowanej przez Komisję Europejską idei stałego sądu arbitrażowego, uznając, że tworzone ad hoc prywatne trybunały arbitrażowe są sprawdzonym rozwiązaniem, dobrym z punktu widzenia amerykańskich korporacji.

Krytycy ISDS oraz ICS proponują inne rozwiązania, które byłyby zgodne z zasadami państwa prawa, a jednocześnie chroniłyby także interesy inwestorów zagranicznych. Chodzi w szczególności o takie dostosowanie krajowych systemów prawnych, by zapewnić wszystkim inwestorom jednakową ochronę prawną. Poza tym inwestorzy zagraniczni, pragnący uzyskać większe zabezpieczenie, mogą np. skorzystać z ubezpieczenia od ryzyka politycznego.

\section{Usługi publiczne w ramach TTIP}

Usługi publiczne, w tym ochrona zdrowia, edukacja, transport, dostawy wody, jak wielokrotnie zapewniała Komisja Europejska, nie są przedmiotem negocjacji dotyczących TTIP. Jednocześnie jednak brak jest podstaw do stwierdzenia, że usługi te są jednoznacznie i trwale wykluczone $z$ tych negocjacji oraz że umowa TTIP nie pociągnie za sobą zmniejszenia ich dostępności dla społeczeństwa. Wręcz przeciwnie, liczne są informacje o tym, że umowa ta nie pozostanie bez wpływu na te usługi. Jedyny rodzaj usług, jakie wyraźnie zostały wykluczone z obszaru, który ma obejmować TTIP, to usługi audiowizualne, ale tylko dotyczące podmiotów działających we Francji. Rząd francuski wykorzystał swoje prawo weta i takiego wykluczenia zażądał.

Stan ten powoduje, że w wielu państwach Unii, w tym nawet w Wielkiej Brytanii, istnieją poważne obawy, że firmy ze Stanów Zjednoczonych, oczekujące na mocy umowy TTIP takiego samego traktowania jak podmiotów z państw członkowskich, będą w stanie przejąć część niezwykle newralgicznych społecznie sektorów, np. ochrony zdrowia i edukacji. Można oczekiwać, że dzięki TTIP nasili się proces wprowadzania 
rynku do sfery usług publicznych. Łatwiejsze niż dotąd stałoby się przechwytywanie przez sektor prywatny środków publicznych przeznaczonych na te usługi, co skutkować może istotnym pogorszeniem dostępu do nich dla większości społeczeństwa. To z kolei będzie czynnikiem powodującym dalszy wzrost nierówności społecznych. Jeżeli usługi publiczne nie zostaną wyraźnie wyłączone w samym tekście umowy TTIP, to zawsze będzie istniało zagrożenie, że amerykańskie korporacje będą starały się wymusić, choćby przez mechanizm ISDS, korzystne dla siebie rozwiązania. Trzeba mieć świadomość, że nie jest możliwe precyzyjne określenie w umowie TTIP wszystkich istniejących usług publicznych, a tym bardziej wskazać takie, które mogą dopiero powstać w przyszłości. Oznacza to, że nawet gdyby podjęto w tej umowie próbę wyraźnego wykluczenia usług publicznych, to zawsze może pozostać jakaś mniejsza czy większa luka, która otworzy pole do niekorzystnych społecznie zmian w usługach publicznych.

W Wielkiej Brytanii dość powszechne są obawy, wyrażane w szczególności przez związki zawodowe, a także przez opozycyjną Partię Pracy, że na podstawie mechanizmu ISDS, który byłby zawarty w umowie TTIP, nie będzie możliwe odejście od ewentualnej prywatyzacji, w tym z udziałem inwestorów ze Stanów Zjednoczonych, przynajmniej części publicznego systemu ochrony zdrowia (National Health System - NHS) oraz innych usług publicznych. Konieczność zapłaty ogromnych odszkodowań zagranicznym korporacjom może okazać się czynnikiem skutecznie odstraszającym władze przed ponownym przekazaniem tych usług pod zarząd państwa ${ }^{36}$. We wrześniu 2015 r. przedstawiciele brytyjskiego rządu przyznali, że kwestia NHS nie została wykluczona z negocjacji w sprawie TTIP, czego wyraźnie domagały się brytyjskie związki zawodowe ${ }^{37}$.

\section{Zasada wzajemnego uznawania norm i standardów}

Jedną z kluczowych zasad, na jakich miałaby się opierać umowa TTIP, jest zasada wzajemnego uznawania standardów (norm) dotyczących towarów znajdujących się $\mathrm{w}$ obrocie na rynkach wewnętrznych stron tej umowy. Jeżeli w ramach porozumienia faktycznie zostałaby zastosowana ta zasada, to mogłoby to prowadzić do obniżenia obowiązujących obecnie w Unii wymagań i podważyć podstawy unijnej ochrony konsumenta i środowiska naturalnego. Jak wskazuje Europejski Komitet Standaryzacji

\footnotetext{
36 P. Ames, ISDS: The most toxic acronym in Europe, op.cit.

37 A. Bennett, NHS Not Safe From Private Firms In Controversial TTIP Deal, UK Admits, http://www. huffingtonpost.co.uk/2014/09/01/ttip-eu-us-trade-deal_n_5747088.html, dostęp 1.09.2014.
} 
(European Committee for Standarization), w ramach legislacji zharmonizowanej w UE, stosowanie planowanej w ramach TTIP zasady wzajemnego uznawania będzie oznaczać uznanie, że obowiązujące w Stanach Zjednoczonych standardy są zgodne z unijnymi wymaganiami dotyczącymi zdrowia i bezpieczeństwa określonymi w regulacjach wydanych na szczeblu Unii (rozporządzenia, dyrektywy). To z kolei będzie umożliwiało wprowadzenie towarów ze Stanów Zjednoczonych do obrotu na rynku całej Unii. Analogiczna sytuacja w odniesieniu do towarów z Unii nie będzie możliwa jednak na rynku amerykańskim, gdyż rząd federalny Stanów Zjednoczonych nie stosuje jednolitego zharmonizowanego modelu dotyczącego standardów, a więc nie ma mechanizmu umożliwiającego temu rządowi przyjmowania jednolitych dla całego kraju oraz wycofywania sprzecznych ze sobą standardów tak, jak to się dzieje na rynku Unii. W rezultacie zastosowanie w ramach TTIP zasady wzajemnego uznawania standardów nie stworzy nowych możliwości dostępu do rynku Stanów Zjednoczonych dla firm z Unii, otworzy zaś jej rynek na import z USA, powodując dodatkowe koszty, utrudnienia i zagrożenia dla europejskich firm i konsumentów ${ }^{38}$. Podobne wnioski zostały zawarte m.in. w raporcie opracowanym na zlecenie Parlamentu Europejskiego, a opublikowanym w lipcu 2015 r. ${ }^{39}$.

W Stanach Zjednoczonych regulacje dotyczące bezpieczeństwa żywności są znacznie mniej restrykcyjne niż w Unii Europejskiej. I tak 70\% przetworzonych produktów rolnych sprzedawanych w Stanach Zjednoczonych zawiera genetycznie modyfikowane składniki. Nie ma obowiązku podawania na etykiecie informacji o tym, że dany produkt takie składniki zawiera. Istnieje poważne ryzyko, że produkty rolne ze Stanów Zjednoczonych, niezawierające takich informacji, po zliberalizowaniu handlu rolnego, mogą znaleźć się na rynku Unii, stwarzając zagrożenie dla konsumentów. Stany Zjednoczone mają też dużo bardziej łagodne regulacje dotyczące stosowania pestycydów, a także hormonów w hodowli bydła, co z kolei jest całkowicie zabronione w Unii ze względu na zwiększone zagrożenie nowotworami dla konsumentów pochodzącego z tej hodowli mięsa. Z kolei, jeśli chodzi o toksyczne substancje chemiczne, to w Unii zakazane jest stosowanie ok. $1200 \mathrm{z}$ nich, podczas gdy w Stanach Zjednoczonych tylko $12^{40}$.

38 The risks of mutual recognition of voluntary standards within the context of a future EU-US trade agreement (TTIP) and alternative approaches, European Committee for Standarization, Brussels 2014, http://www.cencenelec.eu/news/policy_opinions/PolicyOpinions/TTIP_std_mutual_recognition.pdf

${ }^{39}$ J. Pelkmans, The Transatlantic Trade and Investment Partnership (TTIP): Challenges and Opportunities for the Internal Market and Consumer Protection in the Area of Engineering, including Machinery, July 2015, http://www.europarl.europa.eu/RegData/etudes/STUD/2015/542233/IPOL_STU\%282015\%29542233_ EN.pdf

${ }^{40} \mathrm{~L}$. Williams, What is TTIP? And six reasons why the answer should scare you, 12 October 2015, http://www.independent.co.uk/voices/comment/what-is-ttip-and-six-reasons-why-the-answer-shouldscare-you-9779688.html, dostęp 12.10.2015. 
Z punktu widzenia bezpieczeństwa konsumenta istotne znaczenie ma różnica między Stanami Zjednoczonymi a Unią, jeśli chodzi o zasadę odpowiedzialności cywilnej producenta i dystrybutora za produkt. W Unii to podmiot wprowadzający produkt do obrotu musi udowodnić, że jest on bezpieczny, podczas gdy na rynku amerykańskim to użytkownik/konsument tego produktu powinien wykazać, że jest to produkt niebezpieczny.

\section{Tzw. współpraca regulacyjna między Stanami Zjednoczonymi a Unią Europejską}

Istotną metodą, dzięki której wielkie korporacje będą mogły wpływać na proces stanowienia prawa w Stanach Zjednoczonych i państwach Unii Europejskiej, jest tzw. współpraca regulacyjna po wejściu w życie TTIP. Głównym forum dla niej byłaby Rada Regulacyjna (EU - US Regulatory Cooperation Body - RCB) ${ }^{41}$, której utworzenie byłoby jednym z działań planowanych w ramach TTIP. W skład Rady miałyby wchodzić podmioty reprezentujące interesy korporacji uczestniczących w handlu między Stanami Zjednoczonymi a Unią Europejską. Biorąc pod uwagę fakt, że w handlu tym kluczowe znaczenie mają wielkie korporacje, w praktyce Rada Regulacyjna miałaby dbać o to, by planowane do wprowadzenia zmiany legislacyjne nie naruszyły interesów wielkiego biznesu. Prawie każda regulacja może w większym lub mniejszym stopniu wpłynąć na handel transatlantycki, więc Rada Regulacyjna miałaby $\mathrm{w}$ praktyce wielkie możliwości ingerowania $\mathrm{w}$ proces stanowienia prawa realizowany zarówno na szczeblu Unii, jak i odrębnie przez państwa członkowskie.

Zwolennicy TTIP wskazują, że umowa ta może znacząco zmienić polityczne i prawne relacje między Unią Europejską a Stanami Zjednoczonymi oraz stworzyć podstawę do nowej formy globalnego zarządzania gospodarką światową i handlem międzynarodowym dzięki zakładanej w ramach TTIP międzynarodowej współpracy regulacyjnej. W szczególności wskazuje się, że dzięki TTIP będzie historyczna możliwość wyeliminowania różnic w regulacjach prawnych, stanowiących barierę w rozwoju handlu. Współpraca regulacyjna miałaby stanowić swoistą furtkę nie tylko do blokowania nowego ustawodawstwa, ale także działań administracyjnych na wszystkich szczeblach władzy, postrzeganych jako mogące szkodzić rozwojowi handlu między stronami ${ }^{42}$.

${ }^{41}$ TTIP and Regulation: An Overview, The European Commission, Brussels 2015.

42 A. Alemanno, The Regulatory Cooperation Chapter of the Transatlantic Trade and Investment Partnership: Institutional Structures and Democratic Consequences, "Journal of International Economic Law" 2015, September. 
Warto też wskazać, że jeszcze zanim zakończyły się negocjacje w sprawie TTIP, to już miały miejsce specyficzne dostosowania unijnych regulacji do idei przyświecającej tej umowie. Chodzi m.in. o wymagania dotyczące bezpieczeństwa żywności, w tym o ułatwienia we wprowadzaniu na rynek UE produktów rolnych modyfikowanych genetycznie ${ }^{43}$. Zmiany wprowadzone na mocy unijnej dyrektywy 2015/412 wzbudziły poważny niepokój społeczeństwa w wielu państwach członkowskich ${ }^{44}$.

Obawy społeczne może budzić także wiele innych informacji odnoszących się do już istniejącego oraz oczekiwanego wpływu samego procesu negocjacji w sprawie TTIP. Krytycy tej umowy wskazują, że proces negocjacyjny został wykorzystany przez stronę amerykańską do wywarcia presji na Unię Europejską, by zaniechała ona swoich planów dotyczących m.in. wprowadzenia zakazu odnośnie do 31 rodzajów szkodliwych pestycydów. Zwraca się uwagę na to, że lobbyści działający na rzecz wielkich korporacji postrzegają umowę TTIP jako jedną z największych szans, jakie kiedykolwiek istniały, by w sposób systemowy wyeliminować regulacje chroniące konsumentów, pracowników oraz środowisko naturalne ${ }^{45}$.

Dokonując analizy potencjalnych skutków TTIP, warto odwołać się do stwierdzenia wspomnianej już C. Reetz, reprezentującej Europejską Inicjatywę Obywatelską „Stop TTIP”, że „Porozumienie jest takim samym problemem dla UE, jak dla obywateli USA. Powstaje z myślą o korporacjach po obu stronach Atlantyku. To jest starcie pomiędzy społeczeństwem a korporacjami, a my chcemy żyć w społeczeństwie, w którym demokracja będzie większym dobrem niż gospodarka. Nie chcemy demokracji dostosowanej do wymogów rynków, ale rynków, które będą w zgodzie z zasadami demokracji”. Działaczka ta oświadczyła także: „Myślę, że ostatecznie

${ }_{43} \mathrm{~N}$. Dearden, TTIP is already letting big business shape our laws, http://www.independent.co.uk/voices/ttip-is-already-letting-big-business-shape-our-laws-a6700051.html, dostęp 19.10.2015.

${ }_{44}$ Zob. Distrust over EU GM crop approvals grows as 17 countries move towards national bans, http:// www.greenpeace.org/eu-unit/en/News/2015/Distrust-over-EU-GM-crop-approvals-grows-as-at-least13-countries-move-towards-national-bans/, dostęp 1.10.2015. Dyrektywa Parlamentu Europejskiego i Rady (UE) 2015/412 z dnia 11 marca 2015 r. w sprawie zmiany dyrektywy 2001/18/WE w zakresie umożliwienia państwom członkowskim ograniczenia lub zakazu uprawy organizmów zmodyfikowanych genetycznie (GMO) na swoim terytorium, Dz. Urz. UE L 68/1 z 13.03.2015. W dyrektywie tej m.in. stwierdza się, że: „Po zatwierdzeniu GMO przeznaczonych do uprawy zgodnie z unijnymi ramami prawnymi dotyczącymi GMO oraz spełnieniu przez nie, odnośnie do odmiany, która ma zostać wprowadzona do obrotu, wymogów prawa unijnego w zakresie obrotu nasionami i materiałem rozmnożeniowym roślin, państwa członkowskie nie mogą na swoim terytorium zakazać, ograniczyć lub utrudniać swobodnego obrotu nimi, o ile nie mają zastosowania warunki określone w prawie unijnym”. Zgodnie ze wskazaną dyrektywą rządy państw członkowskich mogą wystąpić do firm, które już uzyskały zgodę na uprawy modyfikowane genetycznie, by firmy te nie dokonywały obrotu produktami tych upraw na terytorium tych państw. Firmy te (jak np. Dow, Monsanto, Syngenta, Pioneer) mogą te żądania przyjąć lub odrzucić bez konieczności podawania uzasadnienia.

${ }^{45} \mathrm{~W}$. Louch, TTIP responsible for "dramatically lowering" EU standards, https://www.theparliamentmagazine.eu/print/3479, dostęp 20.10.2015. 
polskie społeczeństwo będzie tak samo przeciwne TTIP jak Niemcy. Ogromna też w tym rola mediów. Sondaże prowadzone w Niemczech pokazały, że im więcej ludzie wiedzą o TTIP, tym bardziej są przeciwni. Nie boją się pozbawieni wiedzy"46.

Umowa TTIP to porozumienie mające na celu niemal całkowitą liberalizację handlu między Stanami Zjednoczonymi a Unią Europejską. Poza zniesieniem ceł ma dotyczyć także wszelkich regulacji postrzeganych przez podmioty uczestniczące w tym handlu jako bariery pozacelne (pozataryfowe). Regulacje te odnoszą się do bardzo wielu dziedzin, $\mathrm{w}$ tym do ochrony środowiska naturalnego, praw konsumenta, bezpieczeństwa żywności, praw pracowniczych. Regulacje te, ukształtowane w Unii Europejskiej w okresie minionych dziesięcioleci, traktowane są przez społeczeństwa państw członkowskich jako te rozwiązania, które chronią prawa żywotne dla obywateli. Firmy uczestniczące w handlu transatlantyckim, a w szczególności wielkie międzynarodowe korporacje, postrzegają jednak te regulacje jako istotną barierę w rozwoju tego handlu, a w rezultacie przeszkodę w zwiększaniu zysków. To właśnie te korporacje są siłą napędową negocjacji w sprawie umowy TTIP. W procesie negocjacyjnym całkowicie pominięta została druga strona, a mianowicie podmioty i instytucje reprezentujące interes pracowników, konsumentów oraz interes publiczny. Jeśli umowa wejdzie w życie, to dla Polski będzie oznaczać ogromny wzrost konkurencji ze strony towarów ze Stanów Zjednoczonych. Będzie to skutkować pozbawieniem naszego państwa szans na prowadzenie suwerennej polityki przemysłowej mającej na celu reindustrializację, a także wykreowaniem wielkich zagrożeń dla rolnictwa, podobnie jak stało się w Meksyku, w efekcie udziału tego państwa w porozumieniu NAFTA. Liberalizacja handlu w ramach TTIP stanie się czynnikiem wymuszającym zwiększoną konkurencję także na polskim rynku, a w rezultacie także presję na zmniejszenie płac oraz innych kosztów, również tych związanych z koniecznością przestrzegania norm i standardów. Planowane niemal powszechne stosowanie, w wyniku tej umowy, zasady wzajemnego uznawania przepisów oznaczać będzie w praktyce obniżenie zabezpieczeń chroniących prawa obywateli, pracowników i konsumentów w Unii Europejskiej. Przewidywany mechanizm rozstrzygania sporów między rządami a zagranicznymi inwestorami oraz tzw. współpraca regulacyjna mogą stać się istotnym czynnikiem podważającym możliwości instytucji Unii Europejskiej oraz władz państw członkowskich w stanowieniu prawa w interesie ogółu obywateli.

${ }^{46}$ L. Raś, op.cit. 


\section{Bibliografia}

Alemanno A., The Regulatory Cooperation Chapter of the Transatlantic Trade and Investment Partnership: Institutional Structures and Democratic Consequences, "Journal of International Economic Law" 2015, September.

Ames P., ISDS: The most toxic acronym in Europe, http://www.politico.eu/article/isds-the-most-toxic-acronym-in-europe/, dostęp 17.09.2015.

Aries, Q., Von Der Burchard H., TTIP negotiations not even half done, "Politico" 2015, October 1.

Baker D., The TPP's Children 's Table: Labor Rights and Currency, http://www.truth-out.org/opinion/item/33572-the-tpp-s-children-s-table-labor-rights-and-currency, dostęp 9.11.2015.

Baker D., The Risks of the Transatlantic Trade and Investment Partnership, "Intereconomics" 2014, No. 3.

Bennett A., NHS Not Safe From Private Firms In Controversial TTIP Deal, UK Admits, http:// www.huffingtonpost.co.uk/2014/09/01/ttip-eu-us-trade-deal_n_5747088.html, dostęp 1.09.2014.

Bureau J.Ch. et al., Risks and Opportunities for the EU Agri-Food Sector in a Possible EU-US Trade Agreement, European Parliament, Directorate-General for Internal Policies, http://www. europarl.europa.eu/RegData/etudes/STUD/2014/514007/AGRI_IPOL_STU\%282014\%295 14007_EN.pdf, dostęp wrzesień 2014.

Capaldo J., The Trans-Atlantic Trade and Investment Partnership: European Desintegration, Unemployment and Instability, Global Development And Environment Institute at Tufts University, GDAE Working Paper 14-03, http://ase.tufts.edu/gdae/policy_research/TTIP_simulations.html, dostęp październik 2015.

Carlsen L., Under Nafta, Mexico Suffered, and the United States Felt Its Pain, http://www.nytimes. com/roomfordebate/2013/11/24/what-weve-learned-from-nafta/under-nafta-mexicosuffered-and-the-united-states-felt-its-pain, dostęp 24.11.2013.

Commission draft text Transatlantic Trade and Investment Partnership Trade In Services, Investment and E-Commerce, http://trade.ec.europa.eu/doclib/docs/2015/september/tradoc_153807.pdf

Commission proposes new Investment Court System for TTIP and other EU trade and investment negotiations Brussels, 16 September 2015, http://europa.eu/rapid/press-release_IP-155651_en.htm

Concept Paper Investment in TTIP and beyond - the path for reform. Enhancing the right to regulate and moving from current ad hoc arbitration towards an Investment Court, European Commission, http://trade.ec.europa.eu/doclib/docs/2015/may/tradoc_153408. PDF, dostęp 5.05.2015.

Dearden N., TTIP is already letting big business shape our laws, http://www.independent. co.uk/voices/ttip-is-already-letting-big-business-shape-our-laws-a6700051.html, dostęp 19.10.2015.

Deaton A., Weak States, Poor Countries, https://www.project-syndicate.org/commentary/economic-development-requires-effective-governments-by-angus-deaton, dostęp 13.10.2015. 
Declassification of document ST 11103/13 Restraint UE/EU Restricted dated 17 June 2013. New status: Public. Directives for the negotiation on the Transatlantic Trade and Investment Partnership between the European Union and the United States of America, Brussels, 11103/13, http://data.consilium.europa.eu/doc/document/ST-11103-2013-DCL-1/en/pdf, dostęp 9.10.2014.

Distrust over EU GM crop approvals grows as 17 countries move towards national bans, http:// www.greenpeace.org/eu-unit/en/News/2015/Distrust-over-EU-GM-crop-approvals-growsas-at-least-13-countries-move-towards-national-bans/, dostęp 1.10.2015.

Dullien S., Garcia A., Janning, J., A Fresh Start for TTIP, “ECFR Policy Brief” 2015, No. 124, European Council on Foreign Relations, www.ecfr.eu

European Commission, Transatlantic Trade and Investment Partnership. The Economic Analysis Explained, http://trade.ec.europa.eu/doclib/docs/2013/september/tradoc_151787.pdf, dostęp wrzesień 2013.

Francois J. et al. Reducing Transatlantic Barriers to Trade and Investment An Economic Assessment Final Project Report, Prepared under implementing Framework Contract TRADE10/A2/A16, Centre for Economic Policy Research, London, http://trade.ec.europa. eu/doclib/docs/2013/march/tradoc_150737.pdf, dostęp marzec 2013.

Frankel J., Why Support the TPP?, https://www.project-syndicate.org/commentary/why-support-tpp-by-jeffrey-frankel-2015-10, dostęp 8.10.2015.

Hamada K., The Fraught Politics of the TPP, https://www.project-syndicate.org/commentary/tppeconomic-gains-political-obstacles-by-koichi-hamada-2015-10, dostęp 31.10.2015.

Hufbauer H.C., Cimino-Isaacs C., How will TPP and TTIP Change the WTO System? "Journal of International Economic Law" 2015, September.

ISDS reform plan retains privileged corporate justice system, http://www.s2bnetwork.org/isds-reform/, dostęp 16.09.2015.

Isfeld G., Forget NAFTA, the TPP is the new 'gold standard' of global trade, http://business. financialpost.com/news/economy/forget-nafta-the-tpp-is-the-new-gold-standard-ofglobal-trade, dostęp 12.10.2015.

Lehmann J.P., TPP: The Path To Global Fragmentation, http://www.forbes.com/sites/jplehmann/2015/10/13/tpp-the-path-to-global-fragmentation/, dostęp 13.10.2015.

Louch W., TTIP responsible for "dramatically lowering" EU standards, https://www.theparliamentmagazine.eu/print/3479, dostęp 20.10.2015.

Neslen A., TTIP: EU negotiators appear to break environmental pledge in leaked draft, http://www. theguardian.com/business/2015/oct/23/ttip-eu-negotiators-appear-to-break-environmentalpledge-in-leaked-draft, dostęp 23.10.2015.

Obama B., America 's bold voice cannot be the only one, "Financial Times" 2015, November 12, http://www.ft.com/cms/s/0/2614c636-8930-11e5-90de-f44762bf9896.html\#axzz3sDKHrBd7

Pelkmans J., The Transatlantic Trade and Investment Partnership (TTIP): Challenges and Opportunities for the Internal Market and Consumer Protection in the Area of Engineering, including Machinery, http://www.europarl.europa.eu/RegData/etudes/STUD/2015/542233/IPOL_ STU\%282015\%29542233_EN.pdf, dostęp lipiec 2015. 
Raś L., Cornelia Reetz o TTIP: Demokracja nie może być dostosowywana do wymogów rynku, http://biznes.gazetaprawna.pl/galerie/898762, duze-zdjecie,1, cornelia-reetz-o-ttip-stop-ttip-isds-ics-wywiad.html, dostęp 9.10.2015.

Raza W., Tröster B., Assessing the Claimed Benefits of the Transatlantic Trade and Investment Partnership, 25-27 September, Rome, http://www2.euromemorandum.eu/uploads/raza_assessing_the_claimed_benefits_of_the_transatlantic_ttip.pdf

Resolution of 8 July 2015 containing the European Parliament's recommendations to the European Commission on the negotiations for the Transatlantic Trade and Investment Partnership, http://www.europarl.europa.eu/sides/getDoc.do?pubRef=-//EP//TEXT+TA+P8-TA$-2015-0252+0+\mathrm{DOC}+\mathrm{XML}+\mathrm{V} 0 / / \mathrm{EN}$

The risks of mutual recognition of voluntary standards within the context of a future EU-US trade agreement (TTIP) and alternative approaches, European Committee for Standarization, Brussels 2014, http://www.cencenelec.eu/news/policy_opinions/PolicyOpinions/TTIP std_mutual_recognition.pdf

Stiglitz J.E., Hersh A.S., The Trans-Pacific Free-Trade Charade, https://www.project-syndicate. org/commentary/trans-pacific-partnership-charade-by-joseph-e--stiglitz-and-adam-s-hersh-2015-10, dostęp 2.10.2015.

TPP es un tratado que nos somete a las farmacéuticas y al poder corporativo, http://www.navarro.cl/tpp-es-un-tratado-que-nos-somete-a-las-farmaceuticas-y-al-poder-corporativo/, dostęp 5.10.2015.

TTIP and Regulation: An Overview, The European Commission, 10 February 2015.

Vattenfall sues Germany over phase-out policy, http://www.world-nuclear-news.org/C-Vattenfall-sues-Germany-over-phase-out-policy-16101401.html, dostęp 16.10.2014.

Weisbrot M., Lessons from NAFTA for the TPP, http://www.cepr.net/publications/op-eds-columns/lessons-from-nafta-for-the-tpp, dostęp 18.10.2015.

Weisbrot M., Lefebvre S., Sammut J., Did NAFTA Help Mexico? An Assessment After 20 Years, Center for Economic and Policy Research, Washington, February 2014.

Wessels A., EU Commission ISDS proposal - threat to democracy, https://edri.org/enditorialeu-commission-isds-proposal-threat-to-democracy/, dostęp 23.08.2015.

Williams L., What is TTIP? And six reasons why the answer should scare you, http://www.independent.co.uk/voices/comment/what-is-ttip-and-six-reasons-why-the-answer-shouldscare-you-9779688.html, dostęp 12.10.2015.

Wise T.A., How Beer Explains 20 Years of NAFTA 's Devastating Effects on Mexico, http://www. globalpost.com/dispatches/globalpost-blogs/global-pulse/nafta-20-years-mexican-beer, dostęp 2.01.2014. 